\title{
Tadeusz Lewowicki, Barbara Chojnacka-Synaszko, Lukasz Kwadrans (red.): Aksjologiczne konteksty edukacji międzykulturowej Cieszyn - Warszawa - Toruń 2015, Wydział Etnologii i Nauk o Edukacji Uniwersytetu Śląskiego, Wyższa Szkoła Pedagogiczna ZNP w Warszawie, Wydawnictwo Adam Marszałek, Stowarzyszenie Wspierania Edukacji Międzykulturowej, ss. 176
}

Problematyka wartości należy do klasycznych w pedagogice. Jednak prądy intelektualne ostatnich dekad - a zwłaszcza te o inspiracjach postmodernistycznych - nie były dla niej łaskawe. Stąd też propozycja publikacji przygotowana przez osoby związane z cieszyńskim wydziałem Uniwersytetu Śląskiego jest niezmiernie interesująca i niezwykle potrzebna. Tym bardziej że tematyka wartości została tu dobrze wpisana w perspektywę wielo- i międzykulturowości.

Tom zawiera teksty przygotowane zarówno przez badaczy o ustalonej pozycji w środowisku naukowym, jak też przez reprezentantów młodszego pokolenia. Zestaw przygotowanych do publikacji tekstów jest daleki od jednorodności i w kilku przypadkach tematycznie odbiega od tytułu całości.

Książkę otwiera tekst Katarzyny Olbrycht, która znakomicie wpisuje obszar wartości i związanej z nią duchowości w edukacyjne konteksty problematyki wielokulturowej rzeczywistości. Autorka podkreśla rolę religijnej duchowości w relacjach międzykulturowych. Wskazuje także za psychologiem religii Pawłem Sochą, że duchowość stanowi differentia specifica gatunku ludzkiego. Autorka pisze o potrzebie stosownych kompetencji w komunikacji międzykulturowej, wskazując, że zwłaszcza $\mathrm{w}$ poszukiwaniu płaszczyzny porozumienia między reprezentantami różnych religii brak kompetencji może prowadzić do różnorodnych nieporozumień, trudności i konfliktów. Swoistym antidotum może tu być uwzględnianie różnych aspektów duchowości. To właśnie wieloaspektowo traktowana duchowość pozwala zdaniem autorki na poszukiwanie „punktów wspólnych lub przynajmniej zbliżonych” i budowanie wokół nich warunków do dialogu. Niezmiernie istotne z pedagogicznego punktu widzenia jest podkreślanie przez autorkę potrzeby konieczności rozwoju duchowości. Zdaniem Katarzyny Olbrycht wynika ona z „długotrwałego tłumienia podmiotowości jednostek i społeczeństw". W opinii autorki - znakomitej znawczyni problematyki - właśnie rozwijany potencjał duchowości może stać się ważnym narzędziem w realizacji idei edukacji międzykulturowej.

Myśląc o duchowości w kontekście tożsamości zbiorowej, zwykle nawiązujemy do religii. W tradycjach naszej części świata zazwyczaj dotyczy to jednej z trzech religii 
monoteistycznych, przede wszystkim chrześcijaństwa. Znacznie rzadziej nawiązuje się do wierzeń przedchrześcijańskich. Tę problematykę podnosi w swoim tekście Krystyna Błeszyńska, zauważając, że w kontekście często analizowanych powiązań między tożsamością etniczną a religią, w odniesieniu do tożsamości polskiej, niezmiernie rzadko nawiązuje się do wierzeń przedchrześcijańskich. Autorka przypomina tu ślady w twórczości Mickiewicza związane z tradycją litewską. Przykładem są choćby znane nam wszystkim ze szkoły Dziady. Tekst jest niezwykle interesujący poznawczo poprzez nawiązywanie do wątków często pomijanych i przez to zapomnianych. Być może w konkluzjach autorka nadaje zbyt duże znaczenie ruchom rodzimowierczym, jednak niewątpliwie mają one swoje miejsce w całym spektrum tożsamości zbiorowych Polaków, które kształtowały się w przeciągu ostatniego tysiąclecia.

Duchowość odgrywa różną rolę nie tylko w różnych religiach, ale także w poszczególnych wyznaniach chrześcijańskich. Niewątpliwie palmę pierwszeństwa dzierży tu prawosławie. Jerzy Nikitorowicz w swoim tekście analizuje ważną przestrzeń prawosławnej duchowości, jaką jest śpiew liturgiczny. Przywołuje przykład nadawania znaczenia muzyce prawosławnej poprzez zainteresowanie nią szerszej publiczności w ramach Festiwalu Muzyki Cerkiewnej w Hajnówce. Autor ukazuje Festiwal głównie jako zjawisko socjologiczne, w którym aspekty duchowości zajmują bardzo ważne miejsce. Istotne w tym kontekście jest przywoływanie przez autora stanowiska Thomasa Luckmana, który wskazywał na postępujący proces prywatyzacji religii. Organizowanie Festiwali Muzyki Cerkiewnej w Hajnówce i Białymstoku koresponduje z tym zjawiskiem w dwojaki sposób. Po pierwsze - nadaje dodatkowe znaczenie części tradycji prawosławnej tym wyznawcom, dla których religijna część ich tożsamości zbiorowej stanowiła istotną wartość. Po drugie Festiwal promuje duchowość prawosławną wśród przedstawicieli innych grup wyznaniowych, pełniąc tym samym ważną rolę w międzykulturowej komunikacji.

Dwa rozdziały w monografii poświęcone są tematyce romskiej. Pierwszy z nich poświęcony jest wprost życiu duchowemu w wymiarze religijnym Romów, a drugi związany jest z obszarem psycholingwistyki. Jak wiadomo, Romowie jako grupa etniczna nie wiążą się z jedną religią i jednym tylko wyznaniem. Stąd troje słowackich autorów, opisując środowisko słowackich Romów, nawiązują do roli dziedzictwa chrześcijańskiego w życiu Romów. Siłą tekstów są egzemplifikacje. Autorzy przytaczają - może nawet nazbyt obszernie - wypowiedzi konkretnych Romów, dotyczące podejmowanej w artykule problematyki. Kolejny tekst poświęcony problematyce romskiej z pozoru jest odległy od kwestii duchowości. Jednak należy podkreślić, że język jest postrzegany przez Romów jako najważniejszy kanał przekazywania i komunikowania Innym własnej kultury, w tym jej duchowej substancji. Łączy się to z niechęcią Romów do udostępniania gadzio tajników własnej duchowości. Z tym bezpośrednio wiązał się dramat poetki romskiej Bronisławy Wajs-Papuszy, przedstawiony przed kilkoma laty w fabularyzowanej, kinowej wersji. Stąd też znaczenie tekstu 
Martina Kaleji i Hristo Kyuchukova daleko wybiega poza jego literalne odczytanie. Moim zdaniem nie zostało to dostatecznie wyraźnie uwzględnione w konkluzjach.

W kolejnych tekstach autorzy w większości znacznie swobodniej nawiązują do tytułu tomu. Tekst Karoliny Czech dotyczy funkcjonowania społeczności religijno-wyznaniowych z nurtu protestanckiego funkcjonujących w Cieszynie. Autorka przedstawia charakterystykę zwłaszcza tych ugrupowań, w których dużą uwagę zwraca się na oddziaływanie Ducha św., w tym Kościoła Zielonoświątkowego. W tekście Ludmiły Choruży jedynie w pierwszych dwu krótkich akapitach autorka próbuje nawiązać do motywu przewodniego książki. Jednak zaproponowaną przez nią tezę trudno uznać za przekonującą. Sprawia raczej wrażenie dosyć doraźnie skomponowanej. Zasadnicza część tekstu dotycząca interakcji między nauczycielem akademickim i studentem stanowi interesujące studium, ale raczej z trudem mieszczące się w ramach niniejszej publikacji. Zdecydowanie bardziej na pograniczu mieści się propozycja Przemysława P. Grzybowskiego. Uśmiech jako instrument komunikowania duchowości jest zaprezentowany przez autora z erudycyjną lekkością i w nienagannym języku. Jest to niewątpliwie tekst oryginalny i wartościowy. Ciekawą propozycję przygotowała także Natalia Maria Ruman. Jej praca wpisuje się w obecny coraz częściej w pedagogice nurt tanatologiczny. W kulturze współczesnej, skupionej raczej na hedonizmie, kwestie śmierci pojawiają się niezwykle rzadko. Jeszcze rzadziej ma to miejsce w naukach o wychowaniu. W praktyce wychowawczej naszych dni ostatni etap ludzkiego życia często jest wstydliwie pomijany. Stąd też propozycję autorki należy ocenić wysoko, tym bardziej że zupełnie sprawnie radzi sobie z trudną problematyką, prowadząc związane $\mathrm{z}$ nią badania i udanie je relacjonując.

Inna interesująca propozycja zawarta w książce dotyczy duchowości zawartej w tradycji lokalnej, która transmitowana jest przy użyciu środków dostępnych teatrowi. Urszula Namiotko przedstawia ciekawą propozycję teoretycznego ujęcia transmisji dziedzictwa kulturowego w ramach działalności teatrów nieprofesjonalnych na Suwalszczyźnie. Z kolei Jarosław Balwin dokonuje próby zaprezentowania duchowego kontekstu wielokulturowości w perspektywie andragogicznej. Jednak autor kończy jedynie na zaprezentowaniu swojej tezy. Trudno uznać za udane jej rozwinięcie i uzasadnienie. Niezwykle interesujące i ważne z perspektywy pedagogiki rozważania znajdziemy w tekście Emilii Żyłkiewicz-Płońskiej. Jednak trudno oprzeć się wrażeniu, że także jej rzetelnie przygotowane i z pasją relacjonowane badania, dotyczące studentów - uczestników programu Erasmus - z trudem mieszczą się w nurcie wytyczonym przez redaktorów tomu.

Konkludując, zamieszczone w tomie teksty w ogromnej większości reprezentują bardzo wysoki poziom naukowy. Spotkanie dojrzałych naukowców z młodym pokoleniem badaczy dało ciekawy efekt, który zadowoli wielu czytelników. Przygotowana przez cieszyńskie środowisko pedagogiczne publikacja może być skierowana zarówno do osób zajmujących się edukacją międzykulturową, jak też 
szerszego grona pedagogów i adeptów pedagogiki. Stanowi ona udaną kontynuację imponującej serii wydawniczej od ponad dwudziestu pięciu lat realizowanej przez naukowe środowisko pod stałym przewodnictwem profesora Tadeusza Lewowickiego. Szczegółową prezentację tej serii znajdziemy zresztą na ostatnich stronach publikacji.

Mirosław Sobecki 